\title{
Michał Madej
}

(Jagiellonian University in Kraków, Poland) https://orcid.org/0000-0001-6694-5320

E-mail: michal.madej@doctoral.uj.edu.pl

\section{The Story About the Green Children of Woolpit According to the Medieval Chronicles of William of Newburgh and Ralph of Coggeshall}

\section{Opowieść o zielonych dzieciach z Woolpit w świetle średniowiecznych kronik Wilhelma z Newburgh oraz Ralpha z Coggeshall}

\section{ABSTRACT}

The Augustinian canon, William of Newburgh, who lived in the 12th century, in his chronicle Historia rerum Anglicarum described an unusual event how in the English village of Woolpit two children appeared that had green skin and spoke an unknown language. This same event was also reported by his contemporary - the Cistercian abbot, Ralph of Coggeshall, in the Chronicon Anglicanum. The main purpose of this paper is a comparative analysis of both versions of the story about the green children and its contextual interpretation. The conducted research indicates that despite relatively small differences between both versions, the story probably fulfilled a different function in the two chronicles. One can put forward a hypothesis in reference to Historia rerum Anglicarum that the fragment about the children from Woolpit is a medium of William of Newburgh's inner anxiety and

\begin{tabular}{|c|c|c|c|c|}
\hline \multicolumn{5}{|c|}{ PUBLICATION INFO } \\
\hline ( $1 \mathrm{H}$ & LIMCS & : & $\begin{array}{l}\text { e-ISSN: } 2449-8467 \\
\text { ISSN: } 2082-6060\end{array}$ & OPEN@ACCESS \\
\hline \multicolumn{5}{|c|}{$\begin{array}{l}\text { THE AUTHOR'S ADDRESS: Michał Madej, the Institute of History of the Jagiellonian University in Kraków, } 24 \\
\text { Gołębia Street, Kraków 31-007, Poland }\end{array}$} \\
\hline \multicolumn{5}{|c|}{ SOURCE OF FUNDING: Financed from the author's own funds } \\
\hline $\begin{array}{l}\text { SUBMITTED: } \\
\text { 2018.07.29 }\end{array}$ & & $\begin{array}{l}\text { ACCEPTED: } \\
2020.01 .14\end{array}$ & $\begin{array}{l}\text { PUBLISHED ONLINE: } \\
2020.12 .21\end{array}$ & (c) \\
\hline \multicolumn{3}{|c|}{$\begin{array}{l}\text { WEBSITE OF THE JOURNAL: } \\
\text { https://journals.umcs.pl/rh }\end{array}$} & $\begin{array}{l}\text { EDITORIAL } \\
\text { COMMITTEE E-mail: } \\
\text { reshistorica@umcs.pl }\end{array}$ & Crossref d \\
\hline
\end{tabular}


trauma - a man who considered himself an Englishman but lived in a Anglo-Norman society. In the case of the second chronicle this story could have had a didactic function and Ralph of Coggeshall probably wanted to draw the attention of his listeners towards what is different, unknown.

Key words: green children of Woolpit, medieval England, Ralph of Coggeshall, William of Newburgh

Medieval chroniclers wrote their works so that the memory of past events would be preserved. However, one has to bear in mind that at that time any history was understood in terms of sacred history - whatever happened, did so for a reason, and in the eyes of a medieval author the reason behind everything was God. Thus, a given chronicle was to assist the readers in attaining salvation, for instance, by demonstrating how the good were rewarded and the wicked - punished. Partly for that reason, annalists of the olden days included in their chronicles not only accounts of events, year after year, but also various testimonies of unusual occurrences: miracles, revelations, visions, and other inexplicable phenomena of the kind $^{1}$. Another stimulus to write about such matters may have been the position taken by St Augustine, who believed that no significant difference exists between what is considered common and unusual, for the greatest of all miracles is the very existence of the world. Hence, according to him, all within the world does in a certain sense constitute a miracle. Therefore, when a chronicler regarded an affair out of the ordinary as something worth noting, he would not hesitate to do $\mathrm{so}^{2}$.

In this paper, I am going to describe and make an attempt at interpreting one of the most unusual events recorded concurrently in a pair of works composed in the English territories - the history behind the discovery of green children. Chronologically, the first to include a mention of it is Historia rerum Anglicarum by the Augustinian canon William of Newburgh (died ca. 1198), written several years before his demise. The author described the events between the Battle of Hastings and the year 1198, when his narrative discontinues ${ }^{3}$. The other work is Chronicon Anglicanum authored by a Cistercian abbot Ralph of Coggeshall (he died after 1227), whose chronicle also opens with the events of 1066 . We are aware, however, that

1 N.F. Partner, Serious Entertainments. The Writing of History in Twelfth-Century England, Chicago 1977, pp. 124-127; C. Watkins, Memories of the Marvellous in the Anglo-Norman Realm, in: Medieval Memories. Men, Women and the Past. 700-1300, ed. E. van Houts, London 2001, p. 93.

2 K. Brewer, Wonder and Skepticism in the Middle Ages, London 2016, pp. 32-34.

3 A. Gransden, Historical Writing in England c. 550 - c. 1307, London 1974, pp. 263-264. 
the records created by him pertain to the period 1187-1224, and that they were written in the $1220 \mathrm{~s}^{4}$.

William of Newburgh wrote that during the rule of Stephen, King of England (1135-1154) in the village of Woolpit (owing its name to the nearby pits, serving as wolf traps), during a harvest from one of such pits, two children emerged: a boy and a girl, siblings. The color of their skin was green, all over. Their attire, crafted of an unknown fabric, was also of an unusual hue. Captured by peasants, they were taken to the village. For several days, the children received no food, and the local community could not come to terms with their bizarre appearance. Eventually, on the verge of their death of starvation, people started giving them food, yet they refused to eat anything. By a complete accident, however, one of the peasants came from his field carrying some broad beans. That prompted the children to search the stems for beans, and when their efforts proved of no avail, they cried. Someone noticed their behavior, opened the pods and took out the beans, that the children ate with mirth. For several months, the children would eat nothing else, until over time they decided to try some bread. At a later stage, they learned the English speech and lost their green skin color. It was then that they came to be christened. Soon afterwards, the little boy died, but his sister was doing well and seemed no different from other people. She was said to have married someone from the village of Lynn.

In a later section of his chronicle, William of Newburgh recorded that when the children had learned the English of the time, they were asked endless questions about many things, above all about who they were and where they had come from. To that, the children answered that they were from 'Saint Martin's Land', who was to be particularly worshipped in the country of their birth. Still, they did not know where that country was situated. They were only able to remember that while shepherding the cattle of their father, they heard something like the tone of bells and while listening to the sound, they experienced a bizarre sensation and for reasons unknown found themselves in Woolpit. Besides that, the children revealed that their homeland was Christian, and they had churches there like in England, but the lands were not lit by the sun; the little light they had was similar to that just before the dawn or shortly after the dusk in England. They also mentioned a certain bright area, visible from 'Saint Martin's Land', but separated from it by a great river $^{5}$.

Ibidem, pp. 322-324.

5 'Historia rerum Anglicarum' of William of Newburgh [hereinafter: HRA], in: Chronicles of the Reigns of Stephen, Henry II and Richard I (Rolls Series, vol. 82), ed. R. Howlett, vol. 1, 
There are several differences in the description of the event provided by Ralph of Coggeshall. The children, though discovered in Woolpit, were brought to the village of Wykes, to the house of Sir Richard de Calne. Together with his household, he became the source of information for the chronicler. After her brother's death, the girl was christened and served the knight, but she was of wanton and arrogant disposition. She later admitted that she had initially thought only broad beans were edible. She also claimed that where she came from everyone and everything was green. She and her brother were to reach Woolpit through a certain cave. To their surprise, they were swept with sunlight and warm air. Although frightened when people wanted to catch them, they were no longer able to find the entrance to the cave ${ }^{6}$.

The connection between these two stories remains unclear. It was normal practice for medieval chroniclers to copy entire passages from works by other authors - at times even word for word - in their own compositions without making any references. In that regard, William of Newburgh and Ralph of Coggeshall were no exceptions (though research has demonstrated that the former made an effort to paraphrase the sources he had used $)^{7}$. It must be ruled out, however, that either of our chroniclers used the other's work, as the texts differ both in language and in style. Nevertheless, the similarity of content is so uncanny that it ought to be assumed that both had the same source . $^{8}$

From the chronicle of William of Newburgh, we learn that he acquired his information about the children from many unnamed persons ${ }^{9}$. Meanwhile, Ralph of Coggeshall is precise in indicating his informants, i.e. Richard de Calne and those closest to him. Furthermore, the abbey of Coggeshall was situated about forty kilometers from Woolpit, so the Cistercian chronicler had no doubt greater chance of finding the origin of the story than William of Newburgh, who recorded it virtually from the other side of England. It would be implausible, therefore, for Ralph

London 1884, pp. 82-84.

6 Radulphi de Coggeshall 'Chronicon Anglicanum'; De expugnatione Terrae Sanctae libellus; Thomas Agnellus: 'De morte et sepultura Henrici regis Angliae junioris'; Gesta Fulconis filii Warini; Excerpta ex 'Otiis imperialibus' Gervasii Tileburiensis [hereinafter: CA] (Rolls Series, vol. 66), ed. J. Stevenson, London 1875, pp. 118-120.

7 A. Gransden, op. cit., p. 264; N.F. Partner, op. cit., pp. 61-62.

8 J. Clark, The Green Children of Woolpit, https://www.academia.edu/10089626/The Green_Children_of_Woolpit [accessed on: 22 I 2019], pp. 38-39.

9 HRA, p. 82. 'Et quidem diu super hoc, cum tamen a multis praedicaretur, haesitavi; remque vel nullius vel abditissimae rationis in fidem recipere ridiculum mihi videbatur: donec tantorum et talium pondere testium ita sum obrutus, ut cogerer credere et mirari, quod nullis animi viribus possum attingere vel rimari'. 
of Coggeshall to base his account of the matter in any way upon that by William of Newburgh. Medievalist John Clark, who paid particular attention to this history, proposed a very convincing hypothesis that in all probability William of Newburgh learned of the story also from Sir Richard de Calne, but through the Augustinians of Thetford, a town in direct vicinity of both Wykes and Woolpit ${ }^{10}$. This hypothesis seems to be additionally corroborated by the fact that the Augustinian of Newburgh was very familiar with the matters related to the part of England near Woolpit, so he must have had a way of acquiring such information, its logical source being the fraternal congregation in Thetford. Similar observation was also put forth by Antonia Gransden in her work on English historiography ${ }^{11}$.

William of Newburgh specified that the discovery of green children occurred during the reign of King Stephen (1135-1154), whereas Ralph of Coggeshall did not directly indicate the period when the event took place (besides the mention of Richard de Calne, but whose exact dates of life are not known $)^{12}$. However, Ralph of Coggeshall set the story between two other tales, which occurred under the reigns of subsequently Henry II Plantagenet (1154-1189) and Richard I Lionheart (1189-1199). That could mean that the green children were found even several scores of years after the death of King Stephen. However, the other stories mentioned, which I will cover later in the article, were not necessarily ordered chronologically, particularly due to the fact that they constitute a digression from the narrative of the Fourth Crusade (1202-1204). Moreover, should we trust William of Newburgh, the girl from Woolpit got married and was still alive not long before the author commenced the work on his chronicle (i.e. several years before 1198). It is, therefore, rather difficult to question the information provided in Historia rerum Anglicarum that the children were discovered during the reign of King Stephen, between 1135 and 1154 . Hence, I believe this chronological range to be the most plausible.

In this unusual tale of green children, one may recognize a motif popular for the medieval stories originating in the territories of England and Wales, that of passing through a cave to another world ${ }^{13}$. Gervase of Tilbury, the author of Otia Imperialia and at the same time one of the people who spoke to Ralph of Coggeshall (a fact that may not have been without its influence on the structure of the latter's tale of green children),

10 J. Clark, op. cit., pp. 38-39.

11 A. Gransden, op. cit., p. 267.

12 J. Clark, op. cit., pp. 44-45.

13 D. Brewer, op. cit., p. 7; C.C. Oman, The English Folklore of Gervase of Tilbury, 'Folklore' 1944, 55, p. 10. 
recounted how during the winter a swineherd from Derbyshire, looking for a lost pig, entered Peak Cavern. He was following the path for a rather long time, when he suddenly noticed the light and the mouth of the cave on the other side, from which the Antipodes spread before him, a land where the seasons were inverted. He saw peasants working on the harvests ${ }^{14}$. Similarly, the 12th-century poet Walter Map provides an account of how the leader of the Wild Hunt, King Herla, reached the land of dwarves, also crossing through a cave ${ }^{15}$. These creatures were to be encountered in the same way by a boy named Eliodor, according to the Itinerarium Cambriae by a 12th-century historian Gerald of Wales; in that world, there was supposed to be a golden castle; however, its beauty was dimmed due to the poor sunlight available in the land of gnomes. Furthermore, the latter were said to be using a language akin to Greek ${ }^{16}$.

There is a similar trope in the tale of green children of Woolpit, who mentioned 'Saint Martin's Land', where the language spoken was not English and everything was covered in semi-darkness. Still, what would be the connection between such a world and the person of Saint Martin? J. Clark cites Anne Witte, a scholar who suspected the world that the children were said to have come from to be associated with the Underworld. She based her conclusions on the fact that St Martin's day (11 November) is celebrated shortly after All Saints' and All Souls' Days, and additionally, at its origin there was a much older Celtic festival, also held in honor of the dead. Although J. Clarke had some reservations regarding the hypothesis, he did not refute it ${ }^{17}$.

At this juncture, two more points are worth drawing attention to, as they could corroborate the hypothesis put forth by A. Witte; the first being the fact that broad beans - initially the only source of nutrition for the green children - had been the symbol of death and corruption since the ancient times, though they were also associated with opposite phenomena, such as rebirth and fertility ${ }^{18}$. In the Middle Ages, broad beans were a popular ingredient of the Lent fast, while in times of famine, they served as a replacement of bread. In spite of the above, a certain mistrust towards the beans prevailed, as physicians of the past would warn against excessive consumption thereof, for it was believed to cause dizziness, problems with sight, and torpor ${ }^{19}$.

14 R. Bartlett, England Under the Norman and Angevin Kings 1075-1225, Oxford 2000, p. 688.

15 C.C. Oman, op. cit., p. 12.

16 Ibidem, p. 11.

17 J. Clark, Martin and the Green Children, 'Folklore' 2006, 117, pp. 208-209.

18 K.M. Briggs, The Fairies and the Realms of the Dead, 'Folklore' 1970, 81, p. 81; M.W. Adamson, Food in Medieval Times, Westport 2004, pp. 5-6.

19 M.W. Adamson, op. cit. 
Another thing, incidentally not explored in J. Clark's research, was the fact that the detail featured in William of Newburgh's version of the story, picturing an undefined bright land across a great river, bears a striking resemblance to a description from a 14th century poem by an anonymous author, titled Pearl $^{20}$. It narrates a story of a man feeling desperate after he lost his pearl. In his sorrow, he falls asleep and dreams of an unearthly beautiful garden, with a stream flowing through it, and on its other bank, there is an unknown land that he believes to be paradise. The medieval motif of an unusual land split by a river may have been popular during the times of William of Newburgh, and still active during the life of the anonymous author of Pearl. Perhaps the latter had access to Historia rerum Anglicarum, though it is a too far-reaching hypothesis, and one based on nothing more than a mere assumption.

In the context of the author of the Pearl, we ought to consider one more aspect of the tale of green children; namely, the very fact that they were 'green'. Indeed, the same anonymous author wrote another famous work: Sir Gawain and the Green Knight. There is no need to discuss the content of that story; nevertheless, the symbolism of green color in the medieval era should be briefly referred to here. Green, much as it is today, used to be associated above all with nature, spring, revival. Additionally, during the Middle Ages it was seen as related to love and sensuality ${ }^{21}$. In the case of the Green Knight, it might have symbolized spring and the vitality of nature, but also, paradoxically, evil and death. Such entirely contradictory symbolism stemmed from the belief, pervasive in medieval England, that the devil likes to wear green robes in order to deceive people, who, seeing him dressed in an easy-on-the-eye color, would be prone to being lured, unable to recognize the devil under such a guise ${ }^{22}$.

However, in the investigated case of the green children, it proves rather difficult to state anything convincing, besides the fact that their unusual color must have had its symbolism and probably also a hidden meaning, no longer perceptible for readers today. It should be remembered that, as remarked by Michel Pastouoreau, we must not apply our contemporary understanding of colors to medieval works, as otherwise we risk committing an act of anachronism. We do not know how colors were perceived by medieval men. In this case, the historian is merely a prisoner of words

${ }^{20}$ C.A.M. Clarke, Signs and Wonders: Writing Trauma in Twelfth-Century England, 'Reading Medieval Studies' 2009, 35, p. 73.

21 J. Hutchings, Folklore and Symbolism of Green, 'Folklore' 1997, 108, pp. 56-57.

22 D. Brewer, The Colour Green, in: A Companion to the Gawain-Poet, eds. D. Brewer, J. Gibson, Woodbridge 1997, pp. 184-185. 
and various kinds of literary devices ${ }^{23}$. Perhaps, in the context of what has already been written here about 'Saint Martin's Land', as a place having much in common with the Underworld, the green color of the children might symbolize, similarly to that of the Green Knight, simultaneously life and death, particularly if we bear in mind that over time the children lost their unusual hue, acquiring more humane tone of skin complexion. It would symbolize the passing from death to life, the revival occurring overground. I will return to the matter later.

The wider interest in the story of the green children of Woolpit dates back to the end of the 16th century, and the first edition of Historiae rerum Anglicarum. In 1610, the work was reissued in an edition where next to the tale of the green children was presented the version written in Ralph of Coggeshall's chronicle ${ }^{24}$. The first reactions to the story that we know of radically differ from one another. William of Camden in his Britannia (1586) saw the tale as a hoax. Meanwhile, the humanist Robert Burton in Anatomy of Melancholy (1621) expressed his conviction that (for whatever reason) the green children had fallen to Woolpit from the Moon. Francis Godwin, the Bishop of Hereford, shared that opinion, which he reiterated in his book Man in the Moone (written between 1626 and 1629). The only difference is, however, that the latter story was one of the first works of science-fiction, it is therefore possible that its author did not treat the Woolpit tale with much earnestness, unlike R. Burton ${ }^{25}$.

The tale of green children came to stir people's imagination starting from 1850, when it was popularized in Fairy Mythology by folklorist Thomas Keightley, the first to publish the story (in the version of Ralph of Coggeshall) not in Latin, that most could not understand, but in English. In this work, the medieval narrative was treated as a folk tale, and the green children were regarded as fairies ${ }^{26}$. Regrettably, the closer to our times, the more we can expect pseudoscientific associations with 'little green men', Martians, and extra-terrestrial civilizations; much could be written about that.

However, more attention is due to those who, believing in literal character of the transmitted content, attempted to approach the issue ration-

${ }_{23}$ M. Pastoureau, Średniowieczna gra symboli, transl. H. Igalson-Tygielska, Warszawa 2006, pp. 133-135.

24 J. Clark, 'Small, Vulnerable ETs': The Green Children of Woolpit, 'Science Fiction Studies' 2006, 33, pp. 210-211.

25 Ibidem, pp. 210-213; S. Hutton, 'The Man in the Moone' and the New Astonomy: Godwin, Gilbert, Kepler, 'Etudes Epistémè' 2005, 7, pp. 3-5; H.W. Lawton, Bishop Godwin's 'Man in the Moone', 'The Review of English Studies' 1931, 7, pp. 38-39.

26 J. Clark, 'Small, Vulnerable ETs', p. 215. 
ally and scientifically, though their conclusions at times prove difficult to accept. I am referring here, most of all, to Derek Brewer and Paul Harris. Both scholars believed the children quite simply got lost in the forest and could not return home, and - due to malnutrition - went down with chlorosis, i.e. 'the green sickness', a form of anemia, resulting in a characteristic greenish hue of the $\mathrm{skin}^{27}$. However, the hypothesis does not stand up to criticism, for it would mean that many persons in 12th-century England suffered from green skin. In this particular case, were we to believe the story at face value, the tone of green of the children's skin must have been something unprecedented and unusual, exceeding the imagination of the inhabitants of Woolpit.

Furthermore, P. Harris was of the opinion that the children had hailed from a family of Flemish immigrants. They were to have been orphaned in 1173, when approximately three thousand Flemish mercenaries fell in the Battle of Fornham St Martin (during a rebellion against the rule of Henry II Plantagenet). That would explain the unknown language spoken by the children ${ }^{28}$. However, it is not easy to accept that theory either, for even though it seems intriguing (particularly due to the toponym which could be identified as 'St Martin's Land'), it contradicts the chronology, because - as mentioned above - William of Newburgh clearly indicated that the green children were discovered during the reign of King Stephen, i.e. between 1135 and 1154. I have my doubts as to a potential mistake made by the chronicler, especially since William of Newburgh lived in the times of the Battle of Fornham St Martin.

Perhaps the basic error displayed by these and many other scholars lies in their attempts to analyze the tale of green children as separate from the entire work or at least from a major section thereof. In such a situation, we are unable to outline the wider context, nor could we determine the purpose the chronicler might have had in featuring such a passage, and whether its message should be considered plausible, or indubitably false. In fact, the chronicles of William of Newburgh and of Ralph Coggeshall constitute two great tales of the English (or, indeed, still Anglo-Norman) people. I have deliberately used here the term 'tale', even though we tend to define chronicles as factual accounts of chronologically organized events, because - as pointed out by Hayden White - chronicles underwent transformations and, enriched by certain motifs, they turned into nothing

27 D. Brewer, Wonder, pp. 182-183; P. Harris, The Green Children of Woolpit: a 12th Century Mystery and its Possible Solution, 'Fortean Studies' 1998, 4, p. 89.

28 P. Harris, op. cit., pp. 90-92. 
else than tales $(\mathrm{H} \text {. White referred to this process as 'fabularisation' })^{29}$. In my opinion, it is only after we have analyzed the history of the green children of Woolpit on the basis of larger fragments drawn from both chronicles, will we be able to put forth hypotheses and seek answers to these intriguing questions.

In the case of Historia rerum Anglicarum by William of Newburgh, the story of the green children of Woolpit is one in a series of four subsequent tales. Before moving on to present them, the chronicler discussed internal affairs, finishing in 1153 with William Fitzherbert returning to the Archdiocese of York, and his rapid demise a year later ${ }^{30}$. Whereas, after he narrated the four stories, William of Newburgh returned to English matters and described the deeds of Prince Henry Plantagenet, the future King Henry II, and the death of Eustace (1153), the son of King Stephen, a development that helped to end the Anarchy in England ${ }^{31}$.

I will now present short outlines of the four stories. The first of these (1) was that of the discovery of the green children. The following one (2) reports an event when after the breaking of a rock two creatures resembling greyhounds were found, both alive even though in the rock they had no access to air. One of them soon died, while the Bishop of Winchester, Henry, took care of the other one. In the third tale (3), similarly, a toad was discovered with a golden chain around its neck. The sight was said to have been so shocking that the rock was reassembled and once again buried in the ground together with the animal. Meanwhile, the final piece (4) tells the story of a drunkard who accidentally came across a passage through the mountains and reached an unusual banquet held on the other side. He was able to steal a beautiful chalice from there, which later came to be the property of King Henry I Beauclerc (1100-1135) 32 .

All four stories noted down by the chronicler share a common motif, that is the discovery of something situated at some depth underground. Each discovery to a certain extent challenges the existing order. According to Catharine Clarke, the author of an enticing work titled Signs and Wonders: Writing Trauma in Twelfth-Century England, William of Newburgh was composing his work under the influence of strong emotions associated with

${ }^{29}$ H. White, Tekst historiograficzny jako artefakt literacki, transl. M. Wilczyński, in: idem, Poetyka pisarstwa historycznego, transl. and eds. E. Domańska, M. Wilczyński, Kraków 2010, p. 82; idem, Fabularyzacja historyczna a problem prawdy, transl. E. Domańska, in: idem, Poetyka pisarstwa, pp. 211-212.

30 HRA, pp. 80-82.

31 Ibidem, pp. 87-90.

32 Ibidem, pp. 84-87 (the three latter stories were grouped in the chapter De quibusdam prodigiosis). 
the situation in England after the civil war of 1135-1153 (i.e. the Anarchy), which interrupted the political order of the country in such a way that the Anglo-Saxon Chronicle spoke of those times that it was when 'Christ and His saints were asleep' ${ }^{33}$. According to the interpretation submitted by C. Clarke, all the abovementioned stories express certain internal restlessness, the trauma experienced by William of Newburgh. On her reading of the narratives, the once-green girl and the dog taken on by the Bishop are a testament to becoming adjusted to England's new situation. The reburied toad, in turn, indicates the consciousness of some evil that has to be completely removed from memory, and the chalice, though nothing out of the ordinary, was beautiful and constituted a souvenir of the place where it had been snatched away from ${ }^{34}$.

The way that the tales were interpreted by $\mathrm{C}$. Clarke constitutes a very intriguing and worth-noting hypothesis; however, I do not understand why the author limited herself to the period of the Anarchy. I believe that these passages from the chronicle by William of Newburgh, particularly the one most interesting for us, could be interpreted more extensively if we returned to the year 1066, that marked the beginning of all the Kingdom's misfortunes: the removal of Old English aristocracy, the introduction of a new model of exercising authority (expressed for instance by the principle - in force in England and practically absent throughout Europe - that 'vassal of my vassal is my vassal'), the imposed system of castle-building (virtually unknown in England until then), the powerful infiltration of the culture of the conquerors from Normandy, and in the long run owing to mixed marriages, the gradual assimilation of the invaders with the former Anglo-Saxons ${ }^{35}$. William of Newburgh, who considered himself to be an Englishman ${ }^{36}$, was no doubt perfectly aware of all of the above. Speaking here of trauma, much like the medievalist Elisabeth van Houts, I would consider the specific burden of experiences that William of Newburgh must have inherited from his parents, or perhaps grandparents; burden that subconsciously transpires - to a greater or lesser extent - throughout his chronicle ${ }^{37}$.

33 English Historical Documents, vol. 2, eds. D. Douglas, G. Greenaway, London 1953, p. 200; 'they said openly that Christ and his saints were asleep'.

${ }^{34}$ C.A.M. Clarke, op. cit., pp. 66-73.

35 Cf. also J.J. Cohen, Green Children from Another World, or the Archipelago in England, in: Cultural Diversity in the British Middle Ages. Archipelago, Island, England, ed. idem, Basingstoke 2008, pp. 85-88.

${ }_{36}$ The Introduction of HRA opens with the words: 'Historiam gentis nostrae, id est, Anglorum [...]', p. 11.

37 E. van Houts, The Trauma of 1066, 'History Today' 1996, 46, pp. 9-15. 
In such circumstances, one could venture into such an interpretation of the tale of green children, in the version of it narrated by William of Newburgh, according to which the facts of their loss of green hue, their acquiring the language of the villagers of Woolpit, and their eating whatever the latter would eat, seem to mirror the transition period from the Anglo-Saxon to the English community (in today's understanding of the word). Thus, the girl from the story would have a double identity. She remembered her own childhood and her roots, but she then became one with the people from England, and even married a man out of her world. On such a reading, the tale would constitute a vehicle for the chronicler's personal beliefs, his thoughts and life experiences. Green children would constitute an alien element, a symbol of the Normans, who over a relatively short period underwent complete assimilation among the subdued inhabitants of England ${ }^{38}$.

Now, if we take a wider look at where the story of green children was situated in the work of Cistercian Ralph of Coggeshall, we will find a similar series of several tales, intertwined into a single major motif. In the case of Chronicon Anglicarum, however, it is not related to the political situation in England, but to the Fourth Crusade (in which Cistercians had an important role to play, as Pope Innocent III commanded their congregation to herald the Crusade; many Cistercians participated in the expedition ${ }^{39}$. At some point in his chronicle, Ralph of Coggeshall made a digression and, much like William of Newburgh, narrated four brief tales.

The first of those (1) is about a wild man - with a pointy beard and matted hair - pulled out of the sea, who said nothing and was religiously indifferent. For some time, he was a ward of a certain knight; however, he later escaped back to the sea ${ }^{40}$. The next (2) is the story of the green children of Woolpit. A later section (3) demonstrates the traces of the presence of giants in the country: their footprints, humongous teeth and skulls, as well as the discovery of an unusually tall man ${ }^{41}$. The final tale in the cycle (4) is about a fantastic spirit, named Malekin, who lived among the family of Osbern de Bradwell in Dagworth. Malekin spoke in a child's voice and could be visible or invisible as he saw fit, he was also able to eat

38 For an extensive treatment of the assimilation of Norman invaders, see: H. Thomas, The English and the Normans: Ethnic Hostility, Assimilation, and Identity 1066 - c. 1220, Oxford 2005, pp. 56-69.

39 E. Freeman, Narratives of a New Order: Cistercian Historical Writing in England, 11501220, Turnhout 2002, p. 204.

40 CA, pp. 117-118.

41 Ibidem, p. 120. 
and people could touch him ${ }^{42}$. Following these four accounts, two other, longer stories can be found, associated with France, that concern heresy and piety, with the main narrative returning to the Fourth Crusade ${ }^{43}$.

As pointed out by researcher Elizabeth Freeman, the common feature of the four stories is that they speak of the bodily appearance of the beings described in them. These resembled people but possessed qualities entirely divergent from the norm, in terms of their looks, color, and size. Now, in the Middle Ages the body was a significant metaphor of the entire society. A healthy body would symbolize a well-operating society, whereas a disfigured one served as the image of a society prone to disintegration. Furthermore, the body was the abode of the soul, which was incomplete without it; hence, at resurrection it would be revived with the body, a teaching particularly preached by St Bernard of Clairvaux. Therefore, any relics free of corruption or exuding a pleasant smell were treated with great reverence as a token of sanctity ${ }^{44}$.

In all four tales presented by Ralph of Coggeshall, the bodies of the persons have certain inhumane elements; thus, they hardly fit into the society, or even constitute a threat to it. According to E. Freeman, by that device the chronicler wanted to direct the attention of his readers to the danger of the 'Other'. Admittedly, attempts can be made at taming what is the 'Other', as in the cases of the green children and the spirit Malekin. However, they are not always successful ${ }^{45}$. Perhaps it was for that reason that the chronicler referred the stories within his narrative of the Fourth Crusade: in order to provide examples that would further stimulate the imagination of a medieval reader or listener, when writing about the contacts between Christians and Muslims, and indeed, considering the actual fate of that expedition, when writing of the cultural differences between the Western and Eastern branch of Christianity.

The above hypothesis, remarks and comments certainly do not exhaust all problems posed by the medieval story of the green children of Woolpit narrated by William of Newburgh and Ralph of Coggeshall. Additionally, this article does not try to find the answer to the crucial question of whether the children actually did exist. There is a common consensus that to every legend and story of the bygone eras there is a grain of truth. It seems to me that so it is also with regard to those children and the point of origin for the story may have been an actual emergence of strange looking people.

\footnotetext{
42 Ibidem, pp. 120-121.

43 Ibidem, pp. 121-129.

44 E. Freeman, op. cit., pp. 210-213.

45 Ibidem.
} 
However, only boundless faith would enable one to accept the fact that these people had come from another world. Such a method of reading the chronicle records must lead one astray. If the green children did exist, the form of their existence must have been different from how it was presented, with their appearance and subsequent fates largely filled in benefit the narrative for the purposes intended by the chroniclers. Obviously, one must remember that part of the story may have been invented by the children themselves ${ }^{46}$.

I tried here to carefully analyze both versions of the story and confront them with the existing research results. Concurrently, I made a goal of studying the tale of green children within the framework of a broader context, not merely as a fragment that could exist separately of the entire work. For it constitutes a crucial and inextricable component of both chronicles, which by way of fabularisation became themselves major tales in the history of England.

For that reason, the story of green children of Woolpit, despite relatively minor differences between the version by William of Newburg and that by Ralph Coggeshall, in all likelihood served two entirely different functions, regardless of how much truth the story holds. It proved intriguing for the pair of chroniclers, who using its plot, whether consciously or not, conveyed their own thoughts, considerations and experiences. In the case of Historiae rerum Anglicarum, one can posit a hypothesis that the tale from Woolpit reflected the anxiety experienced by William of Newburgh - a chronicler who considered himself to be English, but lived in an Anglo-Norman society. Meanwhile, for Ralph Coggeshall, it may have had a didactic function, directing the readers of Chronicon Anglicanum to the threats stemming from what is different and unknown. The above interpretations do not claim to be the only readings of the narrative of green children, one that is bound to forever remain a mystery, unless a new, as yet unknown, historical source is discovered.

(translated by LINGUA LAB)

46 N. Orme, The Culture of Children in Medieval England, 'Past \& Present' 1995, 148, p. 75. The author of the article, in a fragment pertaining to the children's visions, with regard to the events of Woolpit indicated the fact some part of the story of green children may have originated in the childrens' own imagination. Today, we are no longer able to verify which elements in both versions of the medieval story were provided by adults and which by children. However, it should be remembered that such an eventuality does exist. 


\section{REFERENCES}

\section{Printed sources}

English Historical Documents, vol. 2, eds. D. Douglas, G. Greenaway, London 1953.

'Historia rerum Anglicarum' of William of Newburgh, in: Chronicles of the Reigns of Stephen, Henry II and Richard I (Rolls Series, vol. 82), ed. R. Howlett, vol. 1, London 1884.

Radulphi de Coggeshall 'Chronicon Anglicanum'; De expugnatione Terrae Sanctae libellus; Thomas Agnellus: 'De morte et sepultura Henrici regis Angliae junioris'; Gesta Fulconis filii Warini; Excerpta ex 'Otiis imperialibus' Gervasii Tileburiensis (Rolls Series, vol. 66), ed. J. Stevenson, London 1875.

\section{Studies}

Adamson M.W., Food in Medieval Times, Westport 2004.

Bartlett R., England Under the Norman and Angevin Kings 1075-1225, Oxford 2000.

Brewer D., The Colour Green, in: A Companion to the Gawain-Poet, eds. D. Brewer, J. Gibson, Woodbridge 1997.

Brewer K., Wonder and Skepticism in the Middle Ages, London 2016.

Briggs K.M., The Fairies and the Realms of the Dead, 'Folklore' 1970, 81.

Clark J., 'Small, Vulnerable ETs': The Green Children of Woolpit, 'Science Fiction Studies' 2006, 33.

Clark J., Martin and the Green Children, 'Folklore' 2006, 117.

Clarke C.A.M., Signs and Wonders: Writing Trauma in Twelfth-Century England, 'Reading Medieval Studies' 2009, 35.

Cohen J.J., Green Children from Another World, or the Archipelago in England, in: Cultural Diversity in the British Middle Ages. Archipelago, Island, England, ed. J.J. Cohen, Basingstoke 2008.

Freeman E., Narratives of a New Order: Cistercian Historical Writing in England, 1150-1220, Turnhout 2002.

Gransden A., Historical Writing in England c. 550 - c. 1307, London 1974.

Harris P., The Green Children of Woolpit: a 12th Century Mystery and its Possible Solution, 'Fortean Studies' 1998, 4.

Houts van E., The Trauma of 1066, 'History Today' 1996, 46.

Hutchings J., Folklore and Symbolism of Green, 'Folklore' 1997, 108.

Hutton S., 'The Man in the Moone' and the New Astonomy: Godwin, Gilbert, Kepler, 'Etudes Epistémè' 2005, 7.

Lawton H.W., Bishop Godwin's 'Man in the Moone', 'The Review of English Studies' 1931, 7. Oman C.C., The English Folklore of Gervase of Tilbury, 'Folklore' 1944, 55.

Orme N., The Culture of Children in Medieval England, 'Past \& Present' 1995, 148.

Partner N.F., Serious Entertainments. The Writing of History in Twelfth-Century England, Chicago 1977.

Pastoureau M., Średniowieczna gra symboli, transl. H. Igalson-Tygielska, Warszawa 2006.

Thomas H., The English and the Normans: Ethnic Hostility, Assimilation, and Identity $1066-c$. 1220, Oxford 2005.

Watkins C., Memories of the Marvellous in the Anglo-Norman Realm, in: Medieval Memories. Men, Women and the Past, 700-1300, ed. E. van Houts, London 2001.

White H., Fabularyzacja historyczna a problem prawdy, transl. E. Domańska, in: H. White, Poetyka pisarstwa historycznego, transl. and eds. E. Domańska, M. Wilczyński, Kraków 2010.

White H., Tekst historiograficzny jako artefakt literacki, transl. M. Wilczyński, in: H. White, Poetyka pisarstwa historycznego, transl. and eds. E. Domańska, M. Wilczyński, Kraków 2010. 


\section{Non printed studies}

Clark J., The Green Children of Woolpit, https://www.academia.edu/10089626/The_Green_ Children_of_Woolpit [accessed on: 22 I 2019].

\section{STRESZCZENIE}

Żyjący w XII w. kanonik augustiański Wilhelm z Newburgh w swej kronice Historia rerum Anglicarum opisał niezwykłe wydarzenie, jak w angielskiej miejscowości Woolpit pojawiła się dwójka dzieci o zielonej karnacji skóry, mówiąca w obcym języku. Tę samą historię zanotował również inny współczesny mu dziejopisarz - opat cysterski Ralph z Coggeshall, w Chronicon Anglicanum. Głównym celem artykułu jest analiza komparatystyczna dwóch wersji opowieści o zielonych dzieciach oraz jej interpretacja w ujęciu kontekstowym. Przeprowadzone badania wskazują na to, iż mimo stosunkowo niewielkich różnic między przekazem obu kronikarzy, prawdopodobnie pełniła w ich dziełach odmienne funkcje. Można postawić hipotezę, że w odniesieniu do Historiae rerum Anglicarum, fragment o dzieciach z Woolpit jest nośnikiem niepokoju wewnętrznego, traumy Wilhelma z Newburgh - człowieka, który uważał się za Anglika, a żył w społeczeństwie anglonormandzkim. W przypadku zaś drugiej z kronik historia ta mogła pełnić funkcję dydaktyczna, a Ralph z Coggeshall zapewne pragnął zwrócić uwagę swych odbiorców na to, co jest inne, nieznane.

Słowa kluczowe: Ralph z Coggeshall, średniowieczna Anglia, Wilhelm z Newburgh, zielone dzieci z Woolpit

\section{ABOUT THE AUTHOR}

Michał Madej - Graduate of the Institute of History of Jagiellonian University in Kraków and of the Department of Polish Studies of the Jagiellonian University, PhD student in the Faculty of History thereof. His research interests include: history of medieval England (with the particular focus on the Anglo-Saxon period and the transformations occurring in the country after the Norman invasion), history of English literature, Old Polish literature. He is currently working on his doctoral dissertation on the Anglo-Norman identity in historiographic narrative. 